\title{
Extracts of Portulaca oleracea L. growing in Kashmir Valley exert apoptosis mediated antiproliferative effects and inhibit migration and invasion of oral cancer cells
}

\author{
Aadil KHURSHEED ${ }^{1 *}$ (D), Vikrant JAIN 2 (D) \\ 1 Department of Chemistry, Madhyanchal Professional University, Ratibad, Bhopal-462044, M.P, India. \\ 2 Professor at Department of Chemistry, Madhyanchal Professional University, Ratibad, Bhopal-462044, M.P, India. \\ * Corresponding Author. E-mail: aaddikhan12@gmail.com (A.K.); Tel. +91-700-659 5505.
}

Received: 10 May 2021 / Revised: 07 September 2021/ Accepted: 08 September 2021

\begin{abstract}
The main aim of this research was to investigate the antiproliferative effects of $P$. oleracea L. extracts against oral cancer cells and the underlying mechanism of action. The effects of extracts on SCC-9 cell proliferation and colony generation were monitored by MTT (3-(4,5-dimethylthiazol-2-yl)-2,5-diphenyl tetrazolium bromide) assay and clonogenic assay, respectively. Morphological features were studied by phase-contrast microscopy. Apoptotic studies were carried out through AO/EB (Acridine Orange/Ethidium Bromide) staining and western blotting assay. Cell migration and invasion abilities of SCC-9 cells were studied by transwell assay. The results indicated that aqueous, ethanolic and hexane extracts all showed significant $(\mathrm{P}<0.05)$ proliferation inhibition against SCC-9 cells. However, a significant $\mathrm{IC}_{50}$ value was determined in case of ethanolic extract that is $52 \mu \mathrm{g} / \mathrm{ml}$. The number of colonies reduced remarkably post extract treatment. Treated cells showed disturbed morphological features pointing towards apoptotic cell death. It was observed that ethanolic extract caused nuclear disintegration and membrane damage indicated apoptotic cell death, which was further supported by western blotting revealing increased expression of Bax and decreased Bcl-2 expression in treated SCC-9 cells. Furthermore, ethanolic extract significantly blocked the potency of SCC-9 cell to migrate and invade. In conclusion, the results showed that P. oleracea L. possess strong antiproliferative effects against oral cancer cells SCC-9 mediated via apoptosis induction. Moreover, migration and invasion of SCC-9 cells was also inhibited significantly. Therefore, our research could prove beneficial in oral cancer research and treatment and also could help in finding lead drug candidates from $P$. oleracea.
\end{abstract}

KEYWORDS: Oral cancer; Portulaca oleracea; apoptosis; proliferation; cell migration; cell invasion.

\section{INTRODUCTION}

Plants, the most diverse living things on the surface of the earth, have assisted human beings in achieving different livelihood demands since time immemorial [1]. Plants have been a rich resource for food, shelter, medicine, and types of equipment. Medicinal plants are a group of diverse plant species utilized in the treatment of several human disorders. Medicinal plants have endowed human beings with several bioactive and pharmacologically important phytochemicals that are currently a part of modern day pharmaceuticals and some are in later-stage clinical trials. More than $70 \%$ of chemopreventives that have recently entered clinical trials for cancer therapy belong to natural products or designed on them [2].

Portulaca oleracea L. (Figure 1) is a very important medicinal plant growing across the globe [3]. This plant belongs to the family of Portulacaceae and is commonly called as "Ma-Chi-Xian" in China and "purslane" in English [4]. Kashmir Valley horbours a huge diversity of medicinal plants reported with remarkeble contribution in pharmaceutical industry [5]. Portulaca oleracea L. is known as "Nunnar" in Kashmir Valley and is widely distributed as a weed in agricultural crops mainly apple fields. The indigenous people of Kashmir Valley cook aerial parts of the plant and consume it as a vegetable with rice. Portulaca oleracea is salty taste. The plant is considered as very healthy to eat and an immune booster in action. It is a warm-climate, herbaceous succulent annual plant with a cosmopolitan distribution. The plant is an active constituent of various traditional medicine system prescriptions like Ayurveda, Traditional Chinese Medicine and other folk medicines used locally in India especially in Kashmir Valley [6]. Portulaca oleracea has been identified with a huge diversity of chemical constituents responsible for its high medicinal

How to cite this article: Khursheed A, Jain V. Extracts of Portulaca oleracea L. growing in Kashmir Valley exert apoptosis mediated anticancer effects and inhibit migration and invasion of oral cancer cells. J Res Pharm. 2022; 26(1): 154-162. 
importance including terpenoids, fatty acids, polysaccharides, flavonoids, alkaloids, minerals, sterols, vitamins and proteins [7-9]. The broad spectrum of pharmacological efficacies of this plant are already known including antiulcerogenic, anti-inflammatory, antimicrobial, neuroprotective, antidiabetic as well as strong anticancer activity [9-11]. However, molecular mechanism for its anticancer effects is yet to be fully explored.

Oral cancer is a malignant health disorder associated with huge mortality rates worldwide. İn terms of occurence, oral cancer ranks as sixth most frequent cancer across the globe [12]. India is one of the leading countries contributing to the global cancer burden. It is estimated that India contributes one-third to the overall global oral cancer burden [13]. India ranks second in the world in terms of occurence and mortality associated to oral cancer. Of different subtypes, oral squamous cell carcinoma is the most dominant form of oral cancer often detectable in a pre-clinical phase [14]. The most important risk factors contributing to the development of oral cancer are tobacco abuse via chewing, smoke and smokeless tobacco, unhygienic oral cavity, alcohol abuse and long term exposure to viral infections [15]. Dearth of knowledge, disparities in environmental exposure, and behavioral risk factors indicate extensive deviations in the global occurrence and upsurges in the mortality rate associated with oral cancer.

Herein, the current research was designed to evaluate the antiproliferative effects of $P$. oleracea extracts against the oral cancer cells keeping in view the lethality and increasing oral cancer burden. Further, we tried to evaluate the mechanism of action underlying the antiproliferative effects of the extract and also investigated its effects on cell migration and cell invasion of SCC-9 cells.

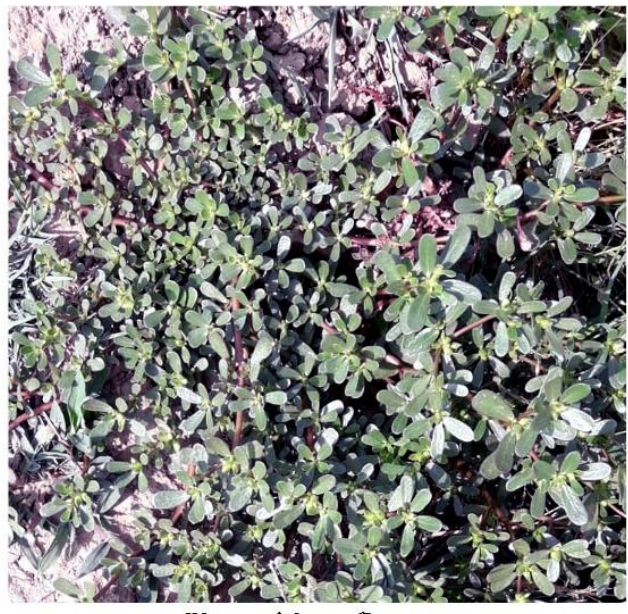

Plant without flowers

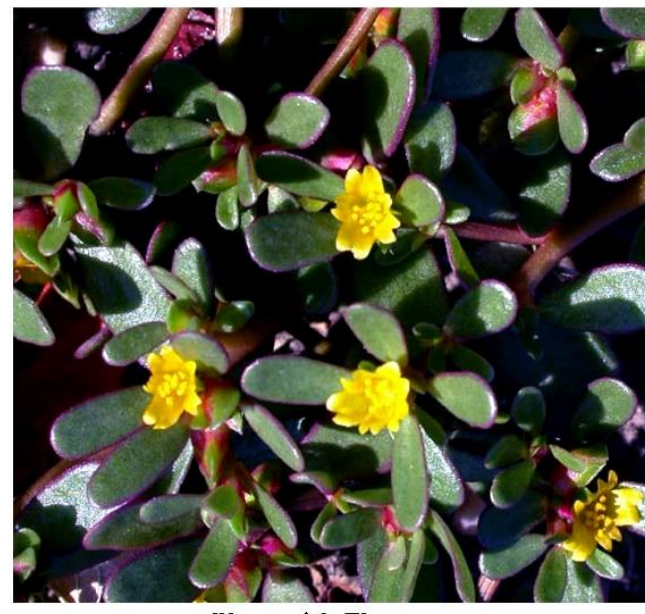

Plant with Flowers

Figure 1. The plant Portulaca olerecia.

\section{RESULTS AND DISCUSSION}

Cancer is a global health issue without any potential treatment stratgey which could completely cure this lethal malignancy. Unfortunately, the oral cancer incidences are up surging at an alarming pace due to high tobacco and alcohol consumption, worldwide. Despite recent advances made in the field of oncology and cancer management strategies, the overall survival rates remain very low. The development of efficient therapeutics and management strategies are the need of the hour for eleminating oral carcinoma. Natural products have always assisted us human beings in achieving our pharmaceutical or livelihood goals [16]. The current research investigation was undertaken to evaluate the antiproliferative effects of different $P$. oleracea extracts against oral cancer SCC-9 cells.

\subsection{Proliferation inhibition of SCC-9 cells by different $P$. oleracea extracts}

Plants have a tremendous potential to manufacturer phytochemicals having broad spectrum of biological applications [17]. The extracts isolated from medicinal plants have shown promising medicinal effects and have remained a pool of different bioactive phytochemicals responsible for these medicinal activities. Plant extracts have been extensivly studied for their antiproliferative property against a wide range of human cancers [18]. P. oleracea is a medicinally important and phytochemically rich species of medicinal plants. Different solvent extracts of this plant have been tested against cancer cells like lung, liver, and breast cancer cells, but no study involved SSC-9 cells with mechanism studies. 
Herein, we for the first time investigated the antiproliferative effects of aqueous, ethanolic and hexane extracts of P. oleracea against SCC-9 cells by performing MTT assay. The SSC-9 cells were exposed to changing concentrations of aqueous, ethanolic and hexane extracts viz $0,40,80,160$ and $320 \mu \mathrm{g} / \mathrm{ml}$ for $48 \mathrm{~h}$, followed by the cell proliferation assessment. All the extracts showed promising antiproliferative effects but the strongest activity was revealed by ethanolic extract followed by aqueous and hexane extracts, respectively $(\mathrm{P}<0.05)$. Ethanolic extract treated cells showed significantly $(\mathrm{P}<0.05)$ decrease in proliferation in a concentration-reliant manner and at higher extract concentration $(160 \mu \mathrm{g} / \mathrm{ml})$ the viable cells reduced to $10 \%$ (Figure 2).

The $\mathrm{IC}_{50}$ value for ethanolic extract was determined and comes out to be $52 \mu \mathrm{g} / \mathrm{ml}$. The aqueous and hexane extracts showed a high $\mathrm{IC}_{50}$ values of $140 \mu \mathrm{g} / \mathrm{ml}$ and $223 \mu \mathrm{g} / \mathrm{ml}$, respectively. Additionally, the ethanolic extract exposure of SCC-9 cells showed tremendous potential and efficacies to inhibit colony generation in the target cells (Figure 3). Therefore, it was concluded that ethanolic extract not only inhibited the proliferation but also inhibited colonies formation by SCC-9 cells.

The aqueous and hexane extracts showed antiproliferative effects but strongest $\mathrm{IC}_{50}$ value was noticed for ethanolic extract. Hence, further mechanism studies were carried out using ethanolic extract treatment against SCC-9 cells.

\subsection{Morphological modifications and apoptotic cell death induced by ethanolic extract in SCC-9 cells}

In multicellular organisms like humans, apoptosis is a natural process that regulates the normal homeostasis of cells, tissues, and organs [19]. The normal homeostasis is maintained by the elimination or disintegration of injured, malfunctioning, damaged and cancer cells. Apoptosis occurs naturally in a programmed manner, therefore it is often refered as type-I programmed cell death. Other naturally reserved death mechanisms include autophagy and necrosis [20]. The over activation of apoptosis results in tissue/cell damage, while its suppression is responsible for pathogenesis of several diseases including cancer. Therefore, a balance between cell death and living is pivotal to maintain normal cell/tissue health. The cancer cells often show decreased apoptosis, making them a prime target for therapies that activate apoptosis [21].

Medicinal plants have been found rich in phytochemical constituents that trigger apoptosis in cancer cells [20]. Earlier studies have demonstrated significant anticancer effects for P. oleracea, but no study has reported antiproliferative effects via apoptosis in SCC-9 cells. Herein, ethanolic extract of P. oleracea treated SCC-9 cells were analysed for morphological features pre and post treatment using phase-contrast-inverted microscopy. Results showed normal cellular morphology in pre-treatment cells while apparent and significant alterations were seen in the morphology and structure of treated SCC-9 cells like cell flouting, appearance of reduced density and round detached cells (Figure 4). These results suggest that SCC-9 cells undergo apoptosis related cell death after extract treatment. Apoptosis was investigated in SCC-9 cells by using acridine orange/ethidium bromide (AO/EB) staining. The pretreatment group showed normal green florescence indicative of regular cell morphology and no apoptotic cell population was seen. Compared to the pretreatment (control) group, the treatment group showed red fluorescent cells, which indicated apoptotic cells, and this red fluorescence increased with increasing plant ethanol extract concentrations (Figure 5). Therefore, AO/EB staining showed enhanced apoptotic percentage in treatment group indicating that the extract induced antiproliferative effects are mediated via apoptosis. The Western blotting assay further confirmed these results, showing that treated cells expressed higher Bax levels and lower Bcl-2 levels. (Figure 6). The Bax is a proapoptotic protein and Bcl-2 is an apoptosis suppressor protein.

Therefore, the above morphological, fluorescence and molecular studies confirm that the antiproliferative effects of ethanolic extract of $P$. oleracea are mediated via triggering of apoptosis.

\subsection{P. oleracea extract inhibited migration and invasion of SCC-9 cells}

Migration and invasion are the two lethal features of malignant cancer cells contributing to metastatic disease [22]. The cancer metastasis is far more dangerous than non-metastatic as it can migrate and invade the neighboring cells, tissues or even distant regions in the body [23]. Hence, suppression of migration and invasion of metastatic cancer cells results in arresting of their metastatic feature and distant disease spread. Plants have been reported with tremendous potential of manufacturing phytochemicals that have antimetastatic property against different human cancer cells [24]. 


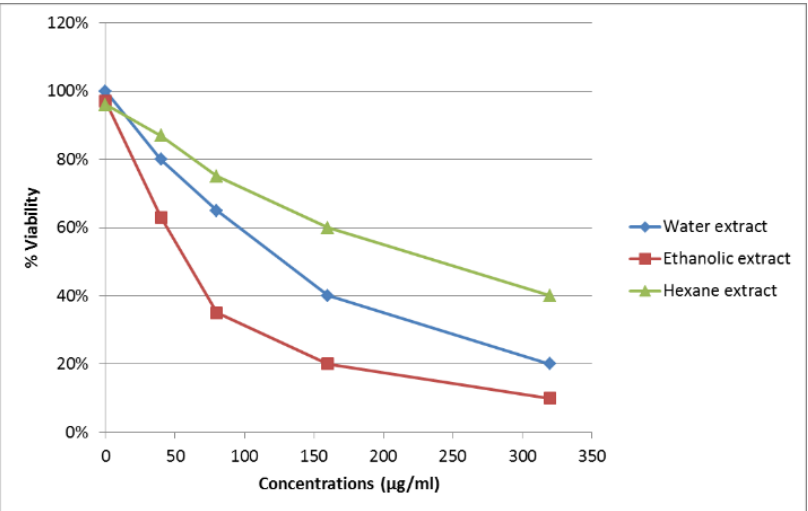

Figure 2. The results of MTT assay designating the antiproliferative activity of different extracts of $P$. oleracea against the SCC-9 cells. Results depicted that all the extracts show remarkable antiproliferative activity while highest activity was reported for the ethanolic extract. All the extract concentrations were experimented in triplicate replicates and data was revealed as mean \pm SD. $\mathrm{P}<0.05$.

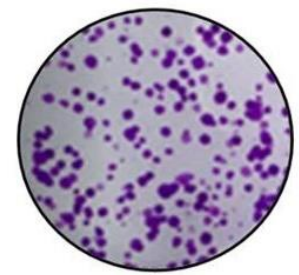

$0 \mu \mathrm{g} / \mathrm{ml}$

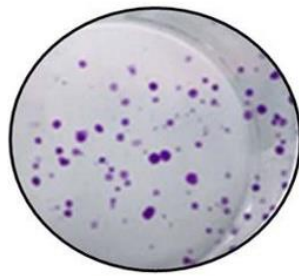

$80 \mu \mathrm{g} / \mathrm{ml}$

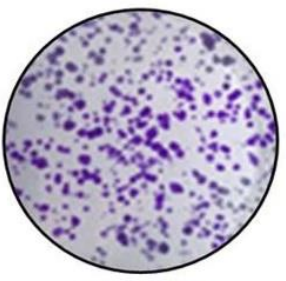

$40 \mu \mathrm{g} / \mathrm{ml}$

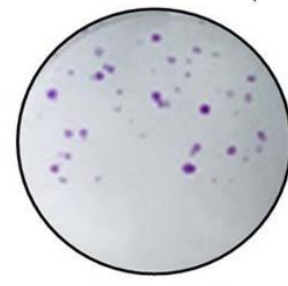

$160 \mu \mathrm{g} / \mathrm{ml}$

Figure 3. Clonogenic assay results showing the SCC-9 cell colonies in treatment and control group of ethanolic extract of $P$. oleracea. The figure clearly indicates reduced number of cell colonies in treatment groups.

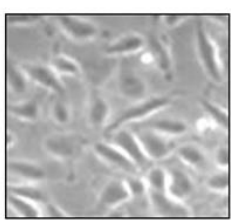

$0 \mu \mathrm{g} / \mathrm{ml}$

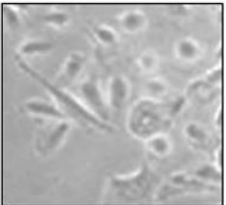

$80 \mu \mathrm{g} / \mathrm{ml}$

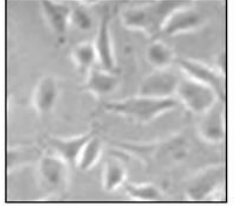

$40 \mu \mathrm{g} / \mathrm{ml}$

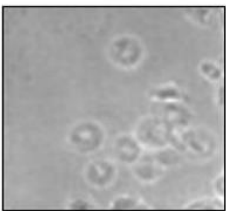

$160 \mu \mathrm{g} / \mathrm{ml}$

Figure 4. Phase contrast inverted microscopy indicating the morphological features of $P$. oleracea extract treated SCC-9 cells and controls. Results showed normal morphology for controls while disturbed morphology showing loss in cell integrity, turbidity and density was seen in treated cells. 
Herein, we evaluated the anti-migration and anti-invasion effects of ethanolic extract of P. oleracea against the metastatic oral cancer SCC-9 cells via transwell chambers assay. Results showed that control group showed significantly higher number of migrated and invaded cells. The number of migrated and invaded cells, as indicated in Figure 7A and B, were significantly lower as compared to that of control group.

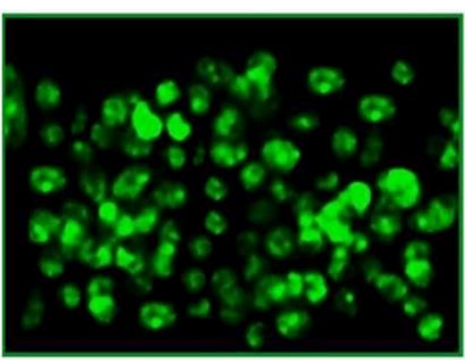

$0 \mu \mathrm{g} / \mathrm{ml}$

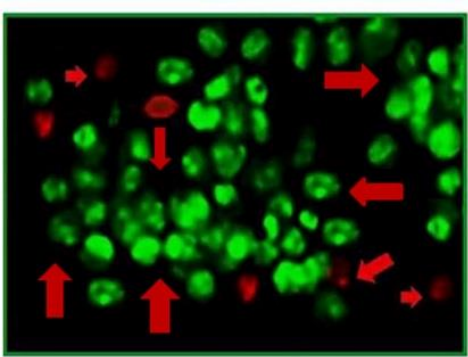

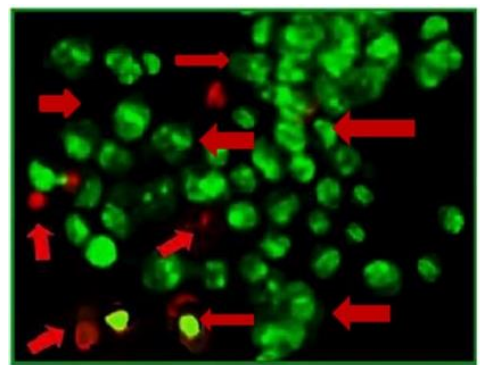

$80 \mu \mathrm{g} / \mathrm{ml}$

$40 \mu \mathrm{g} / \mathrm{ml}$

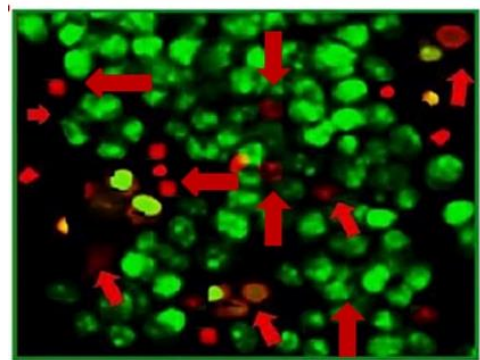

\section{$160 \mu \mathrm{g} / \mathrm{ml}$}

Figure 5. The Acridine Orange/ Ethidium Bromide (AO/EB) staining assay results showing apoptotic cells in treatment and control groups of SCC-9 cells. The arrows point at red-fluorescence indicating apoptotic cells and their number increased with increase in extract concentration as indicated.

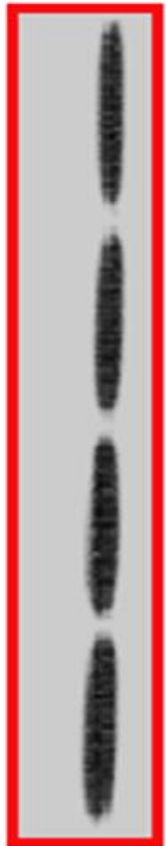

Actin

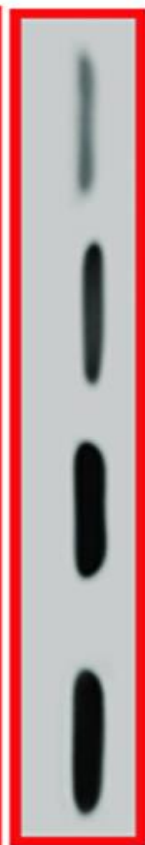

Bcl-2

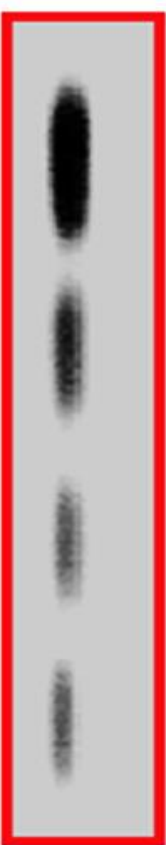

Bax
$160 \mu \mathrm{g} / \mathrm{ml}$

$80 \mu \mathrm{g} / \mathrm{ml}$

$40 \mu \mathrm{g} / \mathrm{ml}$

$0 \mu \mathrm{g} / \mathrm{ml}$

Figure 6. Western blotting showing the expressions of proapoptotic Bax and antiapoptotic Bcl-2 proteins in SCC-9 cells pre and post extract treatment. 

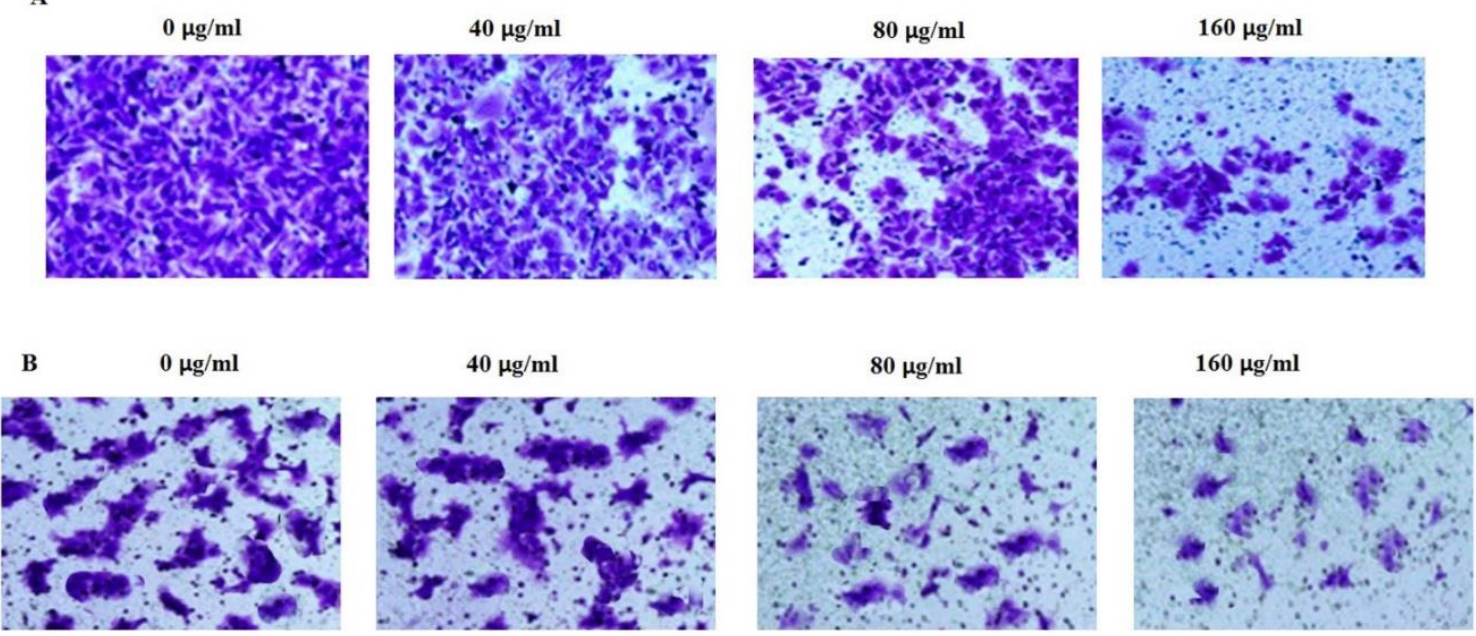

Figure 7. Transwell chambers assay. A) Migration in treated and control SCC-9 cells. B) Invasion in SCC-9 cells pre and post $P$. oleracea ethanolic extract exposure at indicated concentrations.

Hence, these results show that the ethanolic extract of $P$. oleracea possess remarkable tendency to inhibit the migration and invasion propensities of SCC-9 oral cancer cells.

\section{CONCLUSION}

In conclusion, taken together the results showed that aqueous, ethanolic and hexane extracts of Portulaca oleracea L. possess remarkable antiproliferative activity against the oral cancer SCC-9 cells. Ethanolic extract showed highest inhibition, therefore further mechanism studies were carried out using this extract. Results revealed that ethanolic extract inhibited the proliferation, colony generation and induced significant proapoptotic morphological changes in SCC-9 cells. Ethanolic extract induced proapoptotic antiproliferative effects against SCC-9 cells and also inhabited their potency to migrate and invade. Therefore, the plant Portulaca oleracea growing in Kashmir Valley shows remarkable antiproliferative effects against SCC-9 cells. We recommend further phytochemical studies to identify active constituents responsible for strong anticancer activity.

\section{MATERIALS AND METHODS}

\subsection{Collection of plant material}

The plant material of P. oleracea L. was collected from apple orchids of Central Kashmir's Chadoora area $\left(33.9451^{\circ} \mathrm{N}, 74.7966^{\circ} \mathrm{E}\right.$, elevation of 1,577 m), a tehsil in district Budgam, Jammu and Kashmir. The plant was authenticated by Prof. Kanchan Yadav (Department of Botany, Madhyanchal Professional University, Bhopal, Madhya Pradesh) and a specimen was submitted in the Department of Botany, Madhyanchal Professional University bearing voucher specimen no. MPU-B-101. The aerial plant parts including flowers, stem and leaves were collected in month of September and cleaned with tap water. The aerial parts of the plant were shade dried for 3 weeks at a temperature of about $29-30{ }^{\circ} \mathrm{C}$. These parts were cut into small pieces manually and stored in airtight plastic bags to avoid exposure till further use.

\subsection{Preparation of the extracts}

The dried aerial parts of $P$. oleracea were incubated at $50{ }^{\circ} \mathrm{C}$ for $1 \mathrm{~h}$, in order to remove all the retained moisture. Then the plant material was grinded thoroughly till a fine powder is obtained. The powder was suspended in the appropriate solvents choosen in the study $(20 \% \mathrm{w} / \mathrm{v})$ : water, ethanol $(95 \%)$, and hexane $(70 \%)$. For aqueous, ethanolic, and hexane extractions, suspensions were placed under refluxing fitted with magnetic stirrer at $20{ }^{\circ} \mathrm{C}$ for $48 \mathrm{~h}$. Aqueous extract was prepared by boiling the water and plant powder mixture for $3 \mathrm{~h}$. All the suspensions were allowed to settle down and the liquid phase was passed through filtration through Whatman filter paper no. 1 . The filtrate in each case was allowed to dehydrate at $70{ }^{\circ} \mathrm{C}$ with a rotatory evaporator. The final crude extracts were prepared by the mixing each crude extract with dimethyl sulfoxide (DMSO) to obtain a final concentration of $10 \mathrm{mg} / \mathrm{mL}$. These extracts were then stored at 4 ${ }^{\circ} \mathrm{C}$ until further use. 


\subsection{Chemicals, reagents, cell culture and conditions}

All the chemicals and reagents associated to this study were of laboratory grade and provided by the Department of Pharmacy, Madhyanchal Professional University, Bhopal, M.P, India. The SCC-9 malignant oral cancer cell line was obtained from ATCC. The SCC-9 cells were preserved and maintained in RPMI-1640 medium containing antibiotics (penicillin and streptomycin) under humid environment within a $5 \% \mathrm{CO}_{2}$ incubator at a temperature of $37^{\circ} \mathrm{C}$.

\subsection{Proliferation assessment}

The effects of extracts (aqueous, ethanolic and hexane) of P. oleracea on proliferation of SCC-9 cells were examined using MTT assay. Concisely, SCC-9 cells were plated to 96-well plates maintaining a density of $1.3 \times 10^{3}$ cells/well. Then cells were exposed to aqueous, ethanolic and hexane extracts of concentrations viz $0,40,80,160$ and $320 \mu \mathrm{g} / \mathrm{ml}$, for $48 \mathrm{~h}$ at $37^{\circ} \mathrm{C}$. Following treatment, SCC-9 cells were washed in PBS followed by addition of MTT solution. After the addition of MTT, the formazan crystals start to appear in the solution due to the reduction by viable cell components. Therefore, the formazan crystals evolved will be directly proportional to the number of proliferating cells post extract treatments. These formazan crystals were finally dissolved in DMSO and optical density was monitored using a microplate reader. $\mathrm{IC}_{50}$ value was determined by using the concentration at which $50 \%$ of proliferation inhibition was witnessed in SCC-9 cells.

\subsection{Clonogenic assay}

To check the effects of ethanolic extract on clonogenic propensity of SCC-9 cells, we performed clonogenic assay. In brief, the 6-well plates were seeded with about 120-140 cells and left untouched overnight on incubation to let them adhere. After the accomplishment of incubation time, cells were exposed to various concentrations of ethanolic extract of Portulaca oleracea viz 0, 40, 80 and $160 \mu \mathrm{g} / \mathrm{ml}$. Post treatment, cells were decanted of medium and replaced with fresh one and placed under incubation with no disturbance, except replacing medium after 4 days, for 12 days. Finally, the cells colonies were stained using crystal violet and pictured and numbered under a light microscope.

\subsection{Phase contrast microscopy}

SCC-9 cells were placed with a density of $1.5 \times 10^{5}$ cells/well in 6-well plates and precultured for $24 \mathrm{~h}$. After preculturing, cells were exposed to different concentrations of ethanolic extract viz $0,40,80$ and 160 $\mu \mathrm{g} / \mathrm{ml}$ and left on incubation at $37{ }^{\circ} \mathrm{C}$ for $24 \mathrm{~h}$. Afterwards, cells were loaded to a phase contrast inverted microscope (OLYMPUS, Japan) for morphological assessments.

\subsection{AO/EB staining assay}

$\mathrm{AO} / \mathrm{EB}$ staining assay was executed to verify the proapoptotic effects of ethanolic extract of $P$. oleracea. In brief, cells were cultured with a concentration of $1.5 \times 10^{5}$ cells/well of 24 -well plates. Each well plate received different concentration of ethanolic extract viz $0,40,80$ and $160 \mu \mathrm{g} / \mathrm{ml}$ and cultured for $24 \mathrm{~h}$ at $37^{\circ} \mathrm{C}$ in $5 \% \mathrm{CO}_{2}$. Then cells were washed two times in PBS followed by the addition of $10 \mu \mathrm{L}$ of acridine orange/ethidium bromide (AO/EB) and left on incubation in dark for $20 \mathrm{~min}$. Finally, the apoptotic features of SCC-9 cells were detected by using fluorescence microscope (OLYMPUS, Tokyo, Japan).

\subsection{Transwell assay}

Transwell chambers assay was executed to monitor the effects of ethanolic extract on migration and invasion of the oral cancer SCC-9 cells. In brief, the upper transwell chambers were placed with $600 \mu \mathrm{L}$ of RMPI-1640 medium and $1.5 \times 10^{5}$ SCC-9 cells. Lower transwells were placed with medium bearing $10 \%$ fetal bovine serum. Afterwards, different concentrations of the ethanolic extract were added to the upper transwells viz 0, 40, 80 and $160 \mu \mathrm{g} / \mathrm{ml}$ and left on incubation for $24 \mathrm{~h}$. After the accomplishment of incubation period, the non-migrated SCC-9 cells were cleaned off using a cotton swab while migrated cells subjected to fixation with $4 \%$ formalin followed by staining using $0.1 \%$ of crystal violet. The staining last for $20 \mathrm{~min}$ and then migrated cells were numbered and pictured using microscopy at a magnification of 200X.

\subsection{Western blotting}

The extract treated SCC-9 cells were evaluated for proapoptotic and antiapoptotic protein expressions by western blotting. Treated cells $(0-160 \mu \mathrm{g} / \mathrm{ml})$ were lysed using RIPA buffer and lysates were collected for 
protein quantification using BCA assay. Equal amounts of $40 \mu \mathrm{g}$ proteins were separated on SDS-PAGE electrophoretically at $100 \mathrm{~V}$. These proteins were then blotted to PVDF membranes followed by blocking of the membranes with $5 \%$ skimmed milk for half an hour. Post blocking, membranes were subjected to overnight primary antibodies treatment at $4^{\circ} \mathrm{C}$ using anti-Bax (catalog no. sc-7480; 1:1,000 dilutions) and antiBcl-2 (catalog no. sc-7382; 1:1,000 dilutions) (Santa Cruz Biotechnology, Inc., Dallas, United States). Then the primary antibody treatment was followed by secondary antibodies treatment using HRP conjugated goat anti-mouse IgG (catalog no. ab205719; 1:3,000 dilutions; Abcam., Waltham, MA, United States) secondary antibodies for $4 \mathrm{~h}$ in absence of light. The primary and secondary antibody treatments were performed to determine the relative protein concentrations. Actin protein served as standard control in western blot study. Finally, the protein signals were detected using ChemiDoc detection system (Bio-Rad, Hercules, CA, United States).

\subsection{Statistical analysis}

All the individual experimental procedures were repeated in triplicates for each concentration and the data obtained was represented as mean \pm SD. The data was analysed by performing one way ANOVA followed by student's t-test using SPSS software version 15.0. The statistically significant figure was taken as $\mathrm{P}<0.05$.

Acknowledgements: Authors are highly thankful to the Department of Pharmacy and Department of Chemistry, Madhyanchal Professional University for providing Lab space and other necessary equipment's and other components involved in this study.

Author contributions: Concept - A.K., V.J.; Design - A.K., V.J.; Supervision - V.J.; Resources -A.K.; Materials - A.K; Data Collection and/or Processing - A.K.; Analysis and/or Interpretation - V.J., A.K.; Literature Search - A.K.; Writing - A.K; Critical Reviews - A.K., V.J.

Conflict of interest statement: The authors declared no conflict of interest.

\section{REFERENCES}

[1] Rasool A, Bhat KM, Sheikh AA, Jan A, Hassan S. Medicinal plants: Role, distribution and future. J Pharmacogn Phytochem. 2020; 9(2): 2111-2114.

[2] Zabaiou N, Fouache A, Trousson A, Baron S, Zellagui A, Lahouel M, Lobaccaro JM. Biological properties of propolis extracts: Something new from an ancient product. Chem Phys Lipids. 2017; 207: 214-222. [CrossRef]

[3] Londonkar R, Nayaka HB. Phytochemical and antimicrobial activities of Portulaca oleracea L. J Pharm Res. 2011; 4(10): 3553-3555.

[4] Li YH, Lai CY, Su MC, Cheng JC, Chang YS. Antiviral activity of Portulaca oleracea L. against influenza A viruses. J Ethnopharmacol. 2019; 241: 112013. [CrossRef]

[5] Khursheed A, Jain V. Phytochemical screening, antioxidant, and antimicrobial activity of different Portulaca oleracea L. extracts growing in Kashmir Valley. J Biochem Techol. 2021; 12(3): 1-8. [CrossRef]

[6] Ma Y, Li X, Zhang W, Ying X, Stien D. A trace alkaloid, oleraisoindole A from Portulaca oleracea L. and its anticholinesterase effect. Nat Prod Res. 2019; 5: 1-4. [CrossRef]

[7] Yang X, Zhang W, Ying X, Stien D. New flavonoids from Portulaca oleracea L. and their activities. Fitoterapia. 2018; 127: 257-262. [CrossRef]

[8] Nemzer B, Al-Taher F, Abshiru N. Phytochemical composition and nutritional value of different plant parts in two cultivated and wild purslane (Portulaca oleracea L.) genotypes. Food Chem. 2020; 320: 126621. [CrossRef]

[9] Melilli MG, Di Stefano V, Sciacca F, Pagliaro A, Bognanni R, Scandurra S, Virzì N, Gentile C, Palumbo M. Improvement of fatty acid profile in durum wheat breads supplemented with Portulaca oleracea L. quality traits of purslane-fortified bread. Foods. 2020; 9(6): 764. [CrossRef]

[10] Iranshahy M, Javadi B, Iranshahi M, Jahanbakhsh SP, Mahyari S, Hassani FV, Karimi G. A review of traditional uses, phytochemistry and pharmacology of Portulaca oleracea L. J Ethnopharmacol. 2017; 205: 158-172. [CrossRef]

[11] Srivastava R, Srivastava V, Singh A. Multipurpose Benefits of an Underexplored Species Purslane (Portulaca oleracea L.): A Critical Review. Environ Manage. 2021: 1-2. [CrossRef] 
[12] Sur S, Nakanishi H, Steele R, Zhang D, Varvares MA, Ray RB. Long non-coding RNA ELDR enhances oral cancer growth by promoting ILF 3-cyclin E1 signaling. EMBO Rep. 2020; 21(12): e51042. [CrossRef]

[13] Borse V, Konwar AN, Buragohain P. Oral cancer diagnosis and perspectives in India. Sensors International. 2020; 1: 100046. [CrossRef]

[14] Joseph JP, Harishankar MK, Pillai AA, Devi A. Hypoxia induced EMT: A review on the mechanism of tumor progression and metastasis in OSCC. Oral Oncol. 2018; 80: 23-32. [CrossRef]

[15] Börnigen D, Ren B, Pickard R, Li J, Ozer E, Hartmann EM, Xiao W, Tickle T, Rider J, Gevers D, Franzosa EA. Alterations in oral bacterial communities are associated with risk factors for oral and oropharyngeal cancer. Sci Rep. 2017; 7(1): 1-3. [CrossRef]

[16] Blackburn DF, Gill M, Krol E, Taylor J. Natural Health Products and Community Pharmacy - Remove the Mysticism Not the Product. J Pharm Pract. 2017; 30(6): 590-592. [CrossRef]

[17] Khursheed A, Jain V. Medicinal Research Progress of Natural Coumarin and its Derivatives. Nat Prod J. $2020 ; 10: 1$. [CrossRef]

[18] Kooti W, Servatyari K, Behzadifar M, Asadi-Samani M, Sadeghi F, Nouri B, Zare Marzouni H. Effective medicinal plant in cancer treatment, part 2: review study. J Evid Based Complementary Altern Med. 2017; 22(4): 982-995. [CrossRef]

[19] Carneiro BA, El-Deiry WS. Targeting apoptosis in cancer therapy. Nat Rev Clin Oncol. 2020; 17(7): $395-417$. [CrossRef]

[20] Khursheed A, Rather MA, Rashid R. Plant-based natural compounds and herbal extracts as promising apoptotic agents: their implications for cancer prevention and treatment. Adv Biomed Pharma. 2016; 3(04): 245-269. [CrossRef]

[21] Kim C, Kim B. Anti-cancer natural products and their bioactive compounds inducing ER stress-mediated apoptosis: A review. Nutrients. 2018; 10(8): 1021. [CrossRef]

[22] Conlon GA, Murray GI. Recent advances in understanding the roles of matrix metalloproteinases in tumour invasion and metastasis. J Pathol. 2019; 247(5): 629-640. [CrossRef]

[23] Joseph JP, Harishankar MK, Pillai AA, Devi A. Hypoxia induced EMT: A review on the mechanism of tumor progression and metastasis in OSCC. Oral Oncol. 2018; 80: 23-32. [CrossRef]

[24] Gezici S, Şekeroğlu N. Current perspectives in the application of medicinal plants against cancer: novel therapeutic agents. Anticancer Agents Med Chem. 2019; 19(1): 101-111. [CrossRef]

This is an open access article which is publicly available on our journal's website under Institutional Repository at http://dspace.marmara.edu.tr. 